\title{
Zur Problematik der neuen Religionen
}

\author{
Von HARALDS BIEZAIS
}

1. Wir haben uns vorgenommen, in diesem Symposium Fragen zu diskutieren, die hier unter einem gemeinsamen Begriff ,, neue religiöse Bewegungen" zusammengefasst sind. Doch ist eine solche Bezeichnung nicht ganz genau, wie bereits einige der für dieses Symposium angemeldeten Referate zeigen, die sich direkt mit der Frage beschäftigen werden, ob man überhaupt von neuen Religionen sprechen könne oder ob man es mit neuen Erscheinungen in bereits bekannten Religionen zu tun habe. Ohne den vorgesehenen besonderen Erörterungen des Terminus ,"neu“ zuvorkommen zu wollen, müssen hier doch einige Worte über die Schwierigkeiten gesagt werden, die sich gerade aus dem Mangel an einer einheitlichen Terminologie ergeben haben. Ohne diese ist eine ernsthafte wissenschaftliche Diskussion nicht nur erschwert, sondern beinahe unmöglich.

Die Bekanntschaft mit anderen Religionen verdanken wir grossenteils der Tätigkeit der Missionare, und daher wurden auch Bewegungen, die wir heute als neue religiöse Formen ansehen, in der Missionsliteratur entsprechend der in Europa in solchen Fällen verwendeten Terminologie bezeichnet, gewöhnlich als ,Schwarmgeisterei“", damit summarisch alle Bewegungen umfassend, die sich nach Ansicht der Missionare von dem von ihnen verkündeten Christentum unterscheiden. Von deren Standpunkt aus war es auch unwichtig, die besonderen Eigenheiten dieser Bewegungen aufzuzeigen ${ }^{1}$.

1.1 Wenn man sich in die umfangreiche Literatur vertieft, die sich mit diesen Bewegungen beschäftigt, sind drei verschiedene Tendenzen zu beobachten. Erstens wird die neutrale, aber auch nichtssagende Bezeichnung ,Kult" gebraucht ${ }^{2}$, denn zeitweise sind alle religiösen Bewegungen mit einem Kult verbunden. Dieser ist durch die sozialen Verhältnisse bedingt,

\footnotetext{
${ }^{1}$ Dazu haben sich Bergmann, 28 ss; Montauban, $137 \mathrm{ff}$; auch Guariglia, 52, geäussert.

${ }^{2}$ So Smith, Marian 1959a 11; Lommel, 17 ff; Bianchi, $21 \mathrm{ff}$.
} 
unter denen sich gewisse Riten entwickelt haben. Zweitens benutzen Autoren, die diese Bewegungen unter dem Aspekt des Christentums betrachten, eine diesem entsprechende Terminologie, und daher ist die Rede von messianistischen, prophetischen, chiliastischen, millenaristischen und anderen Bewegungen $^{3}$. Das ist nicht nur verständlich, sondern hat auch seinen Grund, denn die Diskussion findet grösstenteils unter Wissenschaftlern statt, die dem christlichen Kulturkreis angehören. Drittens ist eine Gruppe von Termini festzustellen, die sich von der eben erwähnten, vom Christentum her bestimmten Gruppe abhebt. Das kommt daher, weil man berücksichtigen musste, dass sich unter diesen Bewegungen auch solche befinden, die die Tendenz zeigen, zu ursprünglichen religiösen und mythischen Vorstellungen zurückzukehren, die unter besonderen Umständen aufs neue aktuell geworden sind. Dann kann man von nativistischen, revivalistischen und anderen Bewegungen sprechen ${ }^{4}$. Solche Termini werden grossenteils von den aus der angelsächsischen Forschungsrichtung hervorgegangenen Sozialanthropologen und ihren Anhängern benutzt. Oft verwenden verschiedene Forscher zur Bezeichnung ein und derselben Bewegung unterschiedliche Ausdrücke. Man schwankt zwischen undifferenzierten und allgemeinen Ausdrücken einerseits und spezifischen Termini andererseits, die sich bemühen, den besonderen Charakter einer Bewegung darzustellen. Es ist begreiflich, dass in nächster Zeit auf diesem Gebiet der Gebrauch einer einheitlicheren Terminologie nicht zu erwarten ist, wenn man den komplexen Charakter der behand elten Erscheinungen und die verschiedenen Ausgangspunkte der Forscher berücksichtigt. Doch muss man in diese Richtung hin arbeiten, denn die Terminologie ist eine der wichtigsten Voraussetzungen für die wissenschaftliche Untersuchung solcher Erscheinungen.

1.2. Die Frage der Terminologie ist eine Frage von formaler Bedeutung, und daher ist es irrig anzunehmen, dass sie für sich allein zu lösen ist. Sie ist in engem Zusammenhang mit dem Inhalt der Erscheinungen zu betrachten. Mit anderen Worten, nur ein direktes Kennenlernen der Materie selbst erlaubt es, diese vom empirisch Gegebenen in eine formale Kategorie zu er-

\footnotetext{
${ }^{3}$ So Guiart (messianisme); Worsley und Cohn (millenarian movements); Mühlmann (Chiliasmus); Lanternari (Prophetismus) u. a. Dieser Gruppe ist auch Guariglia, 54, mit seinen „Heilserwartungs-Bewegungen" (Salvation movements, mouvements sauveurs, movimenti salvifici) zuzurechnen. Cf. auch van Baaren 1970, 87.

${ }^{4}$ Hier muß insbesondere Linton erwähnt werden, in dessen Fußtapfen viele andere angelsächsische Forscher getreten sind, besonders Wallace u.a.
} 
heben, die dann weiterhelfen kann, diese Bewegungen zu klassifizieren bzw. eine Typologie herauszuarbeiten. So ist es auch verständlich, dass sich dieses Symposium zuerst und hauptsächlich mit solchen konkreten Formen neuer Religionen beschäftigen muss, die die Möglichkeit versprechen, zu grundsätzlichen Erkenntnissen zu gelangen.

2.1. Hier muss man sich jedoch einiger Nebenfragen erinnern. Die Frage nach den neuen Religionen ist gar nicht angebracht, wenn man den Standpunkt einnimmt, wie ihn bis in die letzte Zeit z.B. Zaehner vertritt. Er spricht unter Verwendung der von den Kirchenvätern benutzten Terminologie, von anderen Religionen als von einer praeparatio evangelica. Er stützt sich auf die Ansicht von einem dogmatischen Christentum, das sich in Jesus Worten am Kreuz äussert - consummatum est. ,,Christianity, then, does, fulfil both the mystical tradition of India as finally expressed in the Bhagavad-Gitā and the Bodhisattva doctrine, and the hopes of Zoroaster, the Prophet of ancient Iran. In Christ the two streams meet and are harmonized and reconciled as they are nowhere else: for Christ fulfils both the law and the prophets in Israel and the 'gospel according to the Gentiles' as it was preached in India and Iran." "5

Diese Richtung muss man als absolut ablehnend in bezug auf andere Religionen bezeichnen. Unter dem Einfluss von Barth ist Kraemer in dieser Hinsicht noch weitergegangen, dem es scheint, als ob z.B. die Frömmigkeit der indischen bakhti, in the light of Biblical revelation, commits in this sublime way the root-sin of mankind - 'to be like God'. In other words: he repeats the Fall."6 Ausser der völligen und gänzlichen Offenbarung Gottes durch Jesus haben andere religiöse Offenbarungen keine Bedeutung. Dieser Standpunkt führt unweigerlich zu grossen und unüberwindlichen Schwierigkeiten. Darauf wurde schon mehrfach hingewiesen, denn die geschichtlichen Tatsachen sprechen gegen solche Behauptungen. In diesem Zusammenhang ist an die bezeichnenden Worte von Benz zu erinnern: , Aber auch die christliche Theologie ist geneigt, die neuen Religionen zu ignorieren, ja sogar die Möglichkeit ihrer Entstehung zu bestreiten. Für sie ist das Chri-

\footnotetext{
5 Zaehner, 194.

' Kraemer, 335. Diesen Missionars-Standpunkt Kraemers hat Hallencreutz, 306, anschaulich näher charakterisiert und als typische ,,missionary [!] study of non-Christian religions" erklärt (ib., 298). Eine gute Übersicht über diese Diskussion bietet auch Mensching $58 \mathrm{ff}$. Cf. auch Bouquet, $398 \mathrm{ff}$.
} 
stentum der Abschluß und die Erfüllung der Religionsgeschichte; neue Religionen kann es nicht geben.

Die genannte Einstellung der Religionswissenschaft und der Theologie hat dazu geführt, das Phänomen der neuen Religionen weitgehend zu ignorieren. Inzwischen ist ihr Strom so gewaltig angewachsen, daß man sie nicht mehr ignorieren kann, auch wenn man dies noch so gerne möchte. “7

Diese Situation erkennend, äusserte er die programmatischen Sätze: ,Auch die christliche Theologie mu $\beta$ die Tatsache zur Kenntnis nehmen, da $\beta$ die Religionsgeschichte nach Christus weitergeht. Die christliche Theologie sollte sich vor Augen halten, daß sich das Christentum in seinen Anfangszeiten selbst als neue Religion verstanden hat, die sich nicht nur gegen die hellenistischen Religionen seiner Umwelt abgrenzte, sondern in ihren radikalen häretischen Gruppen, wie etwa den Anhängern des Marcion, auch den geschichtlichen Zusammenhang mit dem Judentum abgestritten hat und durch Ablehnung jeden Zusammenhangs mit der Gottesoffenbarung des Alten Testamentes bewußt zu unterbrechen versuchte. Der Proze $\beta$ der Neubildung von Religionen ging nun auch post Christum weiter: zunächst hat der Manichäismus den Anspruch erhoben, als Universalreligion die wesentlichen Elemente des Christentums, des Zoroastrismus und des Buddhismus zu verbinden und diese älteren Religionen als die abschließende Universaloffenbarung zu überhöhen. Noch stärker hat dann das Auftreten und die weltweite Ausbreitung des Islam zu einer Revision des christlichen Anspruchs geführt." 8

$\mathrm{Zu}$ diesen Gedanken hat Benz noch die Bemerkung gemacht, dass die Herausbildung neuer Religionen noch zur Zeit des Christentums stattgefunden habe, so z. B. des Manichäismus und vor allen Dingen des Islams als weltweite Religion, die sich auf ihre Gottesoffenbarung beruft. Wenn man sich von auf Werturteilen beruhenden und bereits grössenteils überwundenen Ansichten befreit, muss man daher die Frage der Entstehung neuer Religionen positiv beantworten.

2.2. Neben den hier erwähnten Gesichtspunkten sind jedoch auch solche zu bezeichnen, die nicht auf einer indiskutablen dogmatischen Einstellung beruhen, sondern nach einer sinnvollen Erklärung suchen, warum solche Religionen entstehen, indem sie Einblick in die gegebene Situation nehmen.

\footnotetext{
${ }^{7}$ Benz 1971, 7 f. Cf. auch Biezais, 31 f; van Baaren 1972, 9, 37.

${ }^{8}$ Benz, 8 .
} 
Aber auch hier gibt es ausgesprochene Werturteile. Einerseits werden hier Behauptungen aufgestellt, dass die Entstehung neuer Religionen als Ausdruck eines positiven, aktiven religiösen Lebens anzusehen sei. Insbesondere wird das betont im Gegensatz zu Säkularisierungstendenzen in Europa und den USA, einerlei, ob sie als Folge steigenden Wohlstandes, einer rationalen Technokratie oder auch als bewusste, ideologisch begründete Bekämpfung der Religion zu erklären sind. Die weitgeöffneten Kirchentüren für die Bewegung der sog. , Kinder Jesu“ und anderer verschiedener Arten von Hippies, Provies u. a. werden damit begründet, dass es sich um neue, positive religiöse Ausdrucksformen handele, auch wenn sie zum Teil aus der Unzufriedenheit mit der offiziellen Kirche erwachsen, zum Teil unter dem direkten oder indirekten Einfluss verschiedener östlicher Religionen entstanden seien. In diesem Zusammenhang wird von einem direkten Einfluss des Heiligen Geistes und seiner besonderen Wirksamkeit gesprochen.

Daneben werden auch ganz entgegengesetzte Ansichten verkündet, dass die Entstehung neuer religiöser Bewegungen besonders in Europa, aber auch auf anderen Kontinenten einen Beweis für den Verfallsprozess des religiösen Bewusstseins darstelle. Die Berufung der Gründer solcher Religionen auf neue göttliche Offenbarungen, die sie empfangen haben wollen, wird als Ausdruck teuflischer Betrügereien angesehen, und die Begründer dieser Religionen werden als ,,Satans fünfte Kolonne“ bezeichnet ${ }^{9}$. Solche Äusserungen könnte man auch unbeachtet lassen und sie als Oberflächlichkeit ohne tieferes Verständnis für die Erscheinungen ansehen. Doch in engem Zusammenhang damit stehen Versuche, das Aufkommen neuer Religionen mit psychopathologischen Erscheinungen zu erklären. Deren Entstehung bringt man mit einer Abnormität des entsprechenden Begründers der Bewegung in Zusammenhang, die sich auf sexuellem, sozialem, politischem oder wirtschaftlichem Gebiet vollziehe ${ }^{10}$. In der Literatur wird dann von „Massenwahn und psychischen Epidemien" gesprochen"1. Das Schwergewicht wird jedoch stets aufs Kollektiv gelegt. Dass auch diese Erscheinung nicht ausserhalb unseres Beobachtungsgebiets bleiben darf, ist selbstverständlich, aber ebenso begreiflich ist es, dass man es hier mit Vor-

\footnotetext{
9 Darüber im einzelnen Haack, $151 \mathrm{ff}$; auch Natzmer $137 \mathrm{ff}$; Anderson, 108. Katholische Autoren sprechen hier von Häresien (cf. Häresien, 277).

10 Köberle, $159 f$.

${ }^{11}$ Massenwahn $111 \mathrm{ff}, 133 \mathrm{ff}, 173 \mathrm{ff}, 277 \mathrm{ff}$. Weiter zu beachten Schüttler, $149 \mathrm{ff}$; Evans, $10 \mathrm{f}$.
} 
gängen zu tun hat, die, wenn überhaupt, dem analytischen Blick des Religionsforschers nur sehr schwer zugänglich sind.

Die Schwankungen zwischen den verschiedenen Auslegungen und Ansichten in der Frage der Entstehung der neuen Religionen sind verständlich. Sie werden sowohl durch den komplizierten Charakter der zu erforschenden Erscheinungen, als auch durch die Grundhaltung und den ideologischen Standpunkt der Forscher selbst bestimmt. Meiner Meinung nach sollte man sich zurückhalten vor Werturteilen über diese Erscheinungen, die in ihnen eine neue religiöse Renaissance oder - auch umgekehrt - einen Verfallsprozess erblicken. Es kann sich herausstellen, dass die Eingeborenen in Melanesien die ,Kinder Jesu“ als Zeugen des Verfalls ihrer eigenen Religion werten müssen, wogegen mancher Europäer in ihnen Zeugen einer religiösen Wiede rgeburt erkennen möchte.

2.3. Das Hauptproblem jedoch, wenn man die neue religiösen Formen betrachtet, ist das Aufzeigen der Motive, weshalb solche neuen Gebilde gerade heute in solcher Häufigkeit, man möchte fast sagen, mit explosiver Kraft, auftreten. Diese Bewegungen treten in die Geschichte ein und weisen vielfach eine so grosse Anhängerzahl auf, dass man meinen möchte, sie würden von anhaltender und bleibender Bedeutung sein. Es sind nicht nur schnell vorübergehende, episodische Erscheinungen. Das heisst aber noch nicht, dass es nicht auch an religiösen Bewegungen fehlen würde, die in jeder Hinsicht von eingeschränkter und vorübergehender Bedeutung sind.

3.1. Ich möchte hier auf einige Forschungen hinweisen, die sich in letzter Zeit gerade mit diesen Problemen befasst haben. Vor allem sind hier die Arbeiten von Evans zu nennen, die sich von anderen bedeutsam unterscheiden, die sich mit der gleichen Problematik beschäftigt haben. Sein Bildungsstand und Ausgangspunkt sind von anderer Art als bei Religionshistorikern oder Sozialanthropologen. Wir sind es gewohnt, wenn wir von neuen Religionen sprechen, sie unter einen der vorhin genannten Begriffe einzuordnen - Messianismus, Prophetismus, Nativismus, Revivalismus usw., die alle dem Kulturkreis des christlichen Abendlandes entstammen. Aus diesem Grunde bringen sie auch ein gewisses Vorverständnis mit. Evans hat sich für seine Arbeit solche religiöse Erscheinungen zur Untersuchung vorgenommen, die eigentlich mit nicht einem einzigen dieser Termini zu erfassen sind. Er gebraucht diese auch nicht. Statt dessen trifft man in seiner Arbeit für einzelne Abschnitte Überschriften wie die folgenden an: ,, The science fiction religions"; ,,The saviours from the skies", mit Unterabschnitten 
wie: ,Jesus is alive and well and living on Venus"; , Black Boxes" u. a. Es ist hier nicht der Ort weder für eine eingehendere Erörterung dieser verschiedenen Bewegungen, noch für eine Wertung der von Evans geäusserten Gedanken. Doch ist hier ein besonderes Moment zu erwähnen, nämlich Evans' Betonung der Berufung dieser Religionen auf eine bes ondere Offenbarung.

Eine solche Offenbarung hat - erst im März 1954 - Georg King gehabt. In seinem Hause, beim Geschirrspülen, habe er eine Stimme vernommen, die sagte: , Prepare yourself. You are to become the voice of Interplanetary Parliament." Die Überraschung sei so gross gewesen, dass ihm das Geschirr aus der Hand gefallen sei. Er habe diese Stimme noch nie vernommen und habe sie nicht gekannt. Er habe auch noch nie etwas vom ,,Interplanetary Parliament" gehört, daher sei die Überraschung, wie er selbst sagte, sehr gross und eindrücklich gewesen. Einige Tage später sei er aufs neue überrascht worden. In seine Wohnung sei ein schneeweiss gekleideter Mann gekommen, der gesagt habe, dass es um die Menschheit sehr schlecht stehe und dass sie unbedingt der schnellen Hilfe und einer geistigen Erneuerung bedürfe. Georg King sei zu einer grossen Aufgabe ausersehen. Er solle der Diener des , ,Cosmic Master" ${ }^{6}$ werden. Danach nannte sich King auch , Master Aetherius“. In seinem weiteren Leben stand er in Verbindung mit einer höheren Kultur, die er repräsentierte und die ihren Sitz auf der Venus habe. ,,Master Aetherius“ alias King hat auch offen Zeugnis abgelegt über seine Verbindung zu ,,'the Master Jesus', who [...] was alive and well and living on Venus"12. Es erübrigt sich in unserem Zusammenhang, Einzelheiten dieser religiösen Bewegung zu beschreiben. An dieser Stelle interessiert uns nur die Berufung auf eine genuine und ursprüngliche Offenbarung. Möge das Bild grotesk genug sein, die Tatsache bleibt, dass wir es hier mit einem religiösen Erlebnis zu tun haben. Daran würde auch nichts ändern, wenn die Religionspsychologen eine eingehendere Persönlichkeitsanalyse King's vornehmen oder Feststellungen über seine soziale Umwelt treffen bzw. eine Einwirkung sozialer Faktoren auf ihn feststellen würden. Ich möchte diesen Einblick in die ,Aetherian Society" mit Evans' Worten abschliessen: ,For from this original contact and the numerous and

\footnotetext{
12 Evans, 154. ,Jesus survives as a major figure in the Aetherian cult though its adherents are careful to point out that he is 'but one of the Great Masters' and not the divine Son of God" (ib., 155).
} 
voluble communications which followed, arose a minor religious movement which is today the most potent and best-organized of these many groups across the world which relate themselves, in the religious sense, to superior beings from outer space. This is the Aetherius Society, which numbers its supporters in thousands, has branches in most English-speaking countries and offers a complete religious package-deal including prayers, chants, complex rituals, arduous pilgrimages and a fantastic and far-flung philosophy geared to the terminology and iconography of the space age. " 13

Wie ich bereits sagte, ist dies nur ein Beispiel. Evans bietet in seiner Arbeit Einblick in mehrere solcher religiöser Bewegungen ${ }^{14}$.

Dieses Beispiel wirft die Frage auf, welche Motive zur Entstehung der „Aetherian Society“ und ähnlicher Bewegungen geführt haben. Evans' Antwort ist nicht weniger interessant. Zunächst stellt er fest, dass eine merkwürdige Erscheinung zu beobachten sei, die sich sowohl in der Umwelt von ungebildeten Naturvölkern als auch bei Kulturen findet, die sich auf einen philosophischen Monismus stützen. Die grossen Unterschiede bei diesen Völkern in politischer, wirtschaftlicher und sozialer Hinsicht fallen nicht ins Gewicht. Diese Systeme bilden nur den Ausgangspunkt ${ }^{15}$. Ausserdem ist das selbstverständlich, denn alles, was sich in einer gewissen geschichtlichen Situation bildet, ist empirisch bestimmt oder, anders gesagt, trägt den Stempel der Zeit. Daher sind auch alle Versuche und Bemühungen vergeblich, die einzelnen Elemente zu kombinieren und sich auf sie zu stützen, um die neuen religiösen Formen zu erklären. Im Gegenteil, sie lassen sich in höchst grotesker Weise miteinander verbinden. Im Gegensatz dazu sucht Evans die tieferen Wurzeln der neuen religiösen Strömungen und deren Gründe in der gegenwärtigen totalen Situation, nicht in

\footnotetext{
${ }^{13} \mathrm{Ib},, 150 \mathrm{f}$.

14 Ähnliche Formen mit mehr oder weniger deutchlichen ungewöhnlichen und sonderbaren Merkmalen beschreiben auch Haack und Hobsbawn; zurückhaltender sind in dieser Hinsicht Benz und Lanczkowski, die mehr Übersichten traditioneller synkretistischer Formen bieten und sich einer Wertung enthalten.

15 Evans, 13: „,They draw their logic, their language and their philosophy more from the raw material of science, of psychoanalysis and of the existentialist philosophers than from the traditional sources of religion. The mixture is often a bizarre one, but it is evidently potent enough to capture the minds of hundreds of thousands, even millions, of sane men and women on earth today. The students of society among us will watch their evolution with care, and contemporary religious leaders may look to them for possible practical truths, and perhaps even for some useful lessons to be learned."
} 
einzelnen Faktoren. Wenn man die neuen Religionen verstehen will, muss man die totale Situation berücksichtigen. Was charakterisiert diese?

Die gegenwärtige Situation wird durch so umwälzende technologische Veränderungen bestimmt, dass man von einer Revolution sprechen muss. In ihr verliert der Mensch selbst die Sicherheit seiner Existenz und gerät in die sog. ,,drop-out-anarchy". In dieser Lage ruft er um Hilfe. ,,And if science and present-day philosophy - currently obsessed with semantics and linguistics - are unprepared to offer help, while the great world religions offer only outdated, timeworn and implausible concepts, then the field is ripe as never before for stop-gap systems, pseudo-scientific philosophies, quasi-technological cults and new Messiahs to emerge. They are, in fact, already here, and there is evidence that their strength is growing. We shall examine some of them in this book, and when gazed at with a clinical eye they amuse rather than alarm. Yet they beg for careful study for they are sociological phenomena of great interest and significance. Perhaps more important, they give one a taste of things to come, for if the decline of the old-established religions continues at its present pace, and if technology continues to outstrip advances in the philosophy of science, the need for such cults will increase so that not only will they proliferate but some of the existing one will rise to real power. " 16

$\mathrm{Ja}$, aber was bieten denn diese neuen Kulte an? Evans antwortet in seinem eleganten Stil: ,,Man, they proclaim, does have a future, and a future far better, far clearer than the one predicted by orthodox politicians, clergymen and technocrats. For some it is a future where the secrets of life energy - orgone - are harnessed and utilized in the general interests of mankind and the total orgiastic experience; for others it may lie in the coming of Christ anew (in a spaceship) attended by a host of saint-scientist to sort out our desperate problems; for others the future path lies through the evolution of the mind via such systems as Scientology and its various imitations; or perhaps it lies in the tapping of psychic power through partly understood technologies such as radionics. Yet again, it could be that the key to the future will come to us from the past, from those wise priests and sages who sank with Atlantis and whose wisdom yet can be passed on by a chosen few. The list is a long one, and only partly tackled in this book. Hopefully, however, the tackling has been comprehensive enough to make

${ }^{16} \mathrm{Ib} ., 10 \mathrm{f}$. 
the point that the cults, while revealing themselves as insubstantial and occasionally eccentric to the point of being purely funny, nevertheless do their level best to fill a serious vacuum - a vacuum which man has created by his own diligence and scientific curiosity. The truth is that we have been to clever for our own good, and have let our technical mastery of science move far, far ahead of our philosophical and social expertise. With contemptuous ease Man has kicked away from under his feet the bases of his age-old truce with the unknown - the multiple belief systems which we know of as religion. Now that the truce has been broken, the glowing uncertainties of the Universe and the enigma of Man's existence and purpose are revealed only too clearly. It is little wonder that millions of uncertain souls, appalled by this, have striven to make peace again. Many have succeeded, but the terms of the truce have of course been changed. And that is what this book has been about. " 17

Die hier dargelegte Motivierung der neuen Religionen ist, wie ich schon sagte, unter Religionshistorikern nicht üblich, denn deren Blick zur Erklärung dieser Vorgänge bewegt sich sozusagen in horizontaler Linie, d.h. er verfolgt die historischen Tatsachen. Der Religionshistoriker spricht nicht gern von einer Vertikalen, er überlässt sie den Theologen. Doch zwingen die von Evans gegebenen Erklärungen der neuen religiösen Formen aufs neue, sich der Bedeutung der Vertikalen bewusst zu werden, wenn sie sich auch anders darbietet, als wir sie bis jetzt sehen wollten, denn sie verlangt kein Eindringen in die Transzendenz.

3.2. Revolutionär und scharf in seinen Äusserungen ist Jarvie, der sein Werk daher auch ,,The Revolution in Anthropology" genannt hat. Sein Ausgangsmaterial sind die Cargo-Kulte und die damit verbundenen Forschungsergebnisse und dargestellten Standpunkte. Er benutzt dieses Material für eine grundsätzlich neue Erklärung, weshalb die Cargo-Kulte entstanden sind, und zugleich dafür, warum sich überhaupt neue Religionen bilden $^{18}$. Sein Gedankengang ist folgender.

\footnotetext{
17 Ib., $258 \mathbf{f}$.

${ }^{18}$ In dem Vorwort zu Jarvies Buch hat Gellner darauf hingewiesen, daß diese Arbeit zugleich eine gründliche Kritik an dem Struktur-Funktionalismus von Malinowski und Radcliffe-Brown und an ihrem, ,cult of field-work as a necessary precondition" bedeute (Jarvie 1970, VII). Besonders ist hier noch auf Jarvie, 1973, $34 \mathrm{ff}$, hinzuweisen. Bei der Betrachtung von Jarvies Ansichten lassen wir hier seine Versuche unberücksichtigt, die Wissenschaftstheorie von Popper anzuwenden, was meiner Meinung nach in ein Theoretisieren einmündet, wobei der Sinn des historischen Zusammenhangs verlorengeht.
} 
Er erkennt, dass die bisher über die Entstehung der Cargo-Kulte geäusserten Theorien in drei Gruppen eingeteilt werden können: die ProphetenTheorie, die die Entstehung der Cargo-Kulte durch die Aktivität von Personen erklärt, die als Propheten angesehen werden und sich so nennen; die Anhänger-Theorie, die die Entstehung der Kulte mit dem Wunsch und der Aktivität der Anhänger erklärt. Die dritte Gruppe meint, dass diese Kulte ein Resultat der Zusammenarbeit von Prophet und Anhängern seien. Zu all diesen Gruppen von Theorien hat er viele kritische Anmerkungen gemacht, von denen wir hier nur einige erwähnen können. Zur ersten Gruppe bemerkt er, dass es viel mehr Propheten als Cargo-Kulte gäbe, und deshalb könne diese Theorie keine Antwort darauf geben, warum einige Propheten Anhänger haben und andere nicht. Zur zweiten Gruppe äussert er, dass eine Nachfolge nicht nur dem Propheten und seinen Anhängern vorgeschrieben sei, da sie ja nicht in einem Vakuum lebten und tätig seien, sondern in einer bestimmten sozialen Situation und Zeit. Auch zur dritten Gruppe hat er zu bemerken, dass sie, ,can be shown to be unsatisfactory by pointing out that other societies have had the cargo cults happen to them and just because one cult was a product of one situation doesn't mean that every cult was a product of a similar situation ${ }^{19}$. In fact there may be as many different situations as cults, or there may only be one type, or perhaps even the cult diffused through from one 'source' society to spread over to the whole of the Western Pacific. "20

Er gibt zu, alle diese Theorien würden derartige Mängel aufweisen, dass jegliche Erklärungen, falls man sie als solche überhaupt anerkennen könne, unbefriedigend seien. Weil diese Theorien sich strukturell-funktionalistischer Methoden bedienten, seien sie nicht angemessen zur Erklärung der

\footnotetext{
19 Jarvie 1970, $81 \mathrm{ff}$, bietet eine Übersicht mit den Namen der Wissenschaftler, die als Repräsentanten dieser drei Theorien eingeordnet sind. Doch ist zu bemerken, $\mathrm{da} \beta$ er nicht einen einzigen Forscher aufzeigt, der die von ihm genannte erste Theorie vertritt.

20 Jarvie 1970, $81 \mathrm{f}$. Für alle hier genannten kritischen Einwände hat er auch eine umfassende Begründung gegeben (cf. ib., 83-93). In dieser Analyse stellt er in Wirklichkeit die erste Theorie als eine Gruppe von Theorien dar, zudem mit den folgenden Unterabteilungen: ,,expressionistic, intended and unintended ". Ebensolche drei Unterabteilungen verwendet er auch für die zweite Theorie und unterteilt schließlich die dritte Theorie ,,into whole and partial“" (ib., 93). Doch drückt er sich in dieser Frage unklar aus, da er manchmal von Theorien, manchmal von Faktoren spricht. Ferner gibt er zu, dass es praktisch möglich sei, diese insgesamt auch Unterabteilungen verschieden zu kombinieren.
} 
durch die Cargo-Kulte hervorgerufenen sozialen Veränderungen ${ }^{21}$. Ich meinerseits möchte hinzufügen - auch nicht zur Erklärung der religiösen Veränderungen.

Das Erfreuliche bei Jarvie ist, dass er auch seine Theorie, die zum Verständnis der Cargo-Kulte verhelfen könnte, klar formuliert hat. Er nennt sie Situationstheorie ${ }^{22}$. Wie stellen sich die Cargo-Kulte vom Standpunkt der Situationstheorie dar?

„Cults, we have seen, centre round prophets. People listen and do what the prophet asks them - A) Why? Because what he says is in accord with their general outlook and solves their urgent problems. (B) Why then are cargo cult doctrines what we know them to be? Because they were created as hypotheses to explain certain facts, solve certain problems raised by the presence of the white man. The explanations are within the magicoreligious framework of the culture. (C) Why then are the cults similar from place to place? Because of diffusion; the diffused ideas are accepted so frequently because they suit these relatively homogeneous social situations well. (D) Why are the cults apocalyptic and millenarian? My suggestion is because of the situation which arises when a closed society is undergoing change. Before going into detail I have to say a few words to explain Popper's idea. “23

Nach diesem Bekanntwerden mit Jarvies Theorie können wir uns wieder dem Grundproblem zuwenden und fragen: Was bietet seine Theorie zum

21 Jarvie 1970, 159; ,Because cargo cults are externally caused change, no structuralfunctional explanation of them (as opposed to their effects or receptions) can be given. This, in my view, is the most powerful reason why none has been given or, so far as I am aware, attempted; we need no longer find this lack surprising." "

${ }^{22}$ Ib., 105.

${ }^{23} \mathrm{Ib} ., 114$. Zu dieser grundsätzlichen Behauptung hat er auch eine eingehende Erklärung geboten. Er ist sich jedoch auch der Einwände bewußt, die gegen seine Theorie erhoben werden könnten: ,I want in this chapter to discuss in a little more detail several criticisms of cargo cult theories, criticisms which can also be used to allege the unsatisfactoriness of the situational logic solution. These criticisms say situational logic is no good: (a) because it explains these religious movements rationally and these movements in particular and even religion in general are not rational; $(b)$ because it tries to explain all these cults together whereas each one is a unique phenomenon; $(c)$ because it does this by assuming that the people in this situation are acting rationally, but they are not; $(d)$ because it does this by assuming that what people believe or say they believe will explain what they do, but this is false." (Ib., 131.)

Er hat ihnen auch längere Erklärungen beigefügt (ib., 131-169). Doch verläuft diese Diskussion auf rein theoretischer Ebene, so daß wir sie hier beiseite lassen. 
Verständnis der neuen Religionen? Die Situationstheorie erlaubt es, diese Erscheinungen auf drei Ebenen zu sehen. Als Grundebene hat er eine glaubhafte Erklärung für die sozialen und religiösen Veränderungen gegeben, die mit zeitlich und geographisch beschränkten Erscheinungen - den CargoKulten - verbunden sind. Aber da die Cargo-Kulte typologisch zu einer grösseren Gruppe von Religionsbewegungen gehören, die sich durch manche allgemeine und ähnliche Züge auszeichnen, nämlich den Millenarismus, so erweitert die Situationstheorie die Möglichkeiten, auch auf dieser zweiten Ebene solche Bewegungen besser zu verstehen. Auch auf der dritten Ebene bietet diese Theorie bessere Möglichkeiten des Verständnisses. Hier möchten wir nur an die von Evans erwähnten Bewegungen erinnern ${ }^{24}$.

Doch ist hierzu gleich eine kritische Anmerkung zu machen, dass man nicht ohne eine gewisse Kühnheit bei den Cargo-Kulten von Diffusion sprechen kann, wie das Jarvie tut. Besonders erschwert ist das auf der zeiten Ebene, wenn von messianistischen Bewegungen allgemein gesprochen wird. Eine gewisse Ähnlichkeit in den Grundzügen gibt dazu kein Recht. Jedenfalls, ungeachtet der kritischen Bemerkungen, die man zur Theorie Jarvies machen kann, ist sie dennoch ein bedeutender Schritt vorwärts zum theoretischen Verständnis der Herausbildung neuer Religionen. Besonders im Vergleich zu Evans hebt sich die Position Jarvies deutlicher ab. Der erstere hält sich an die Beschreibung empirisch gegebener Vorgänge und gibt sich bestenfalls mit einer psychologischen Erklärung derselben zufrieden. Der andere ist ein reiner Wissenschaftstheoretiker, der erkennt, dass das wissenschaftliche Verständnis einer Erscheinung nur möglich ist auf Grund einer richtigen Theorie ${ }^{25}$. Die Ansichten sowohl Evans' als auch Jarvies

\footnotetext{
${ }^{24}$ In diesem Zusammenhang lohnt es sich, in die gute Übersicht von Voget, insbesondere in die Tabelle, Einsicht zu nehmen.

${ }_{25}$ Über die bisherigen Versuche hat er sich sehr skeptisch geäussert, ihnen fehle eine klare theoretische Grundlage: ,,Not only are problems not strictly separated off from one another (even in the longer tracts of Worsley and Burridge), but an astonishing, almost bewildering, variety of different sorts of explanations is paraded, often mixed up together. There are economic explanations, sociological explanations (i.e. explanations within situational logic and especially explaining facts as unintended consequences), socio-cultural explanations, historical explanations, psychological explanations, diffusionist explanations and evolutionist (often enough historicist) explanations.

Yet with no exceptions these explanations stand outside the official explanatory framework of British social anthropology. Since these authors were often structural-functionalists tackling a problem which, according to their own claims at least, should have been accessible to their doctrines, and since their explanation by-passed it, they are in a definite sense unsatisfactory." (Jarvie 1970, 161.)
} 
unterscheiden sich bedeutend von den bisherigen Ansichten der Religionshistoriker und Sozialanthropologen. Die Diskussion, besonders über die sogenannten revolutionären Ansichten des letzteren, war ausserordentlich lebhaft ${ }^{26}$, doch ist es jetzt nicht möglich, sie weiter zu verfolgen. Doch muss hier auf einen grundsätzlichen Unterschied der Standpunkte zu den bisherigen Erklärungen hingewiesen werden, der weitere fruchtbare Diskussionen auslösen könnte. Ich wähle hier Lanternari aus.

3.3. Lanternari hat der deutschen Ausgabe seines bekannten Buches ,Movimenti religiosi di libertà e di salvezza dei popoli opressi“" ein besonderes Vorwort eingefügt, in dem er beachtenswerte Gedanken über das Verständnis der Sozialanthropologen von der messianistischen Bewegung äussert. Er schreibt: ,Die meisten 'Sozialanthropologen' quälen sich mit dem sogenannten Deutungsproblem, oder 'problem of explanation', das sie traditionellerweise folgendermaßen stellen: 'Wie ist es zu erklären, daß Bewegungen dieser Art in einigen Gebieten oder unter einigen Gruppen nicht entstehen, in denen die herrschenden Umstände denjenigen Bedingungen analog sind, die in anderen Gebieten und Gruppen für das Entstehen neuer Kulte entscheidend sind?' In dieser Formulierung scheint mir das Problem falsch gestellt zu sein [...]. “27

Er weist ferner auf den Unterschied hin, der grundsätzlich zwischen einer historisch gegebenen Bewegung im Gegensatz zu jeglichem theoretischen System besteht. Die erstere verläuft als ein dynamischer Prozess der Veränderung und Neuschöpfung, während ein System nur eine stabile Tradition feststellen könne. Er lehnt daher die Versuche der Sozialanthropologen ab, denn sie ,,sind nicht imstande, die verschiedenen Möglichkeiten in der 'Geschichte' zu erfassen: das Entstehen nämlich verschiedener Typen von kollektiven Antworten auf Krisensituationen. Der Historiker formuliert demzufolge die Frage nicht etwa so: 'Warum ist eine solche Bewegung nicht entstanden?': Man kann keine Geschichte dessen, was nicht existiert, schreiben. Vielmehr lautet die Frage so: 'Welche Antwort unter denen, die möglich und real waren, wurde in diesem Fall gewählt und gegeben? Welche besondere Art von Reaktion oder 'Bewegung' ist unter dem Druck von ähnlichen Krisenfaktoren entstanden?' Man wird sich außerdem fragen müssen: 'Was waren die entscheidenden Gründe für diese Antwort? Handelt es

\footnotetext{
${ }^{26}$ Cf. Anm. 20.

${ }^{27}$ Lanternari, $17 \mathrm{f}$.
} 
sich um soziokulturelle Faktoren, oder um Faktoren individueller Art, die mit Persönlichkeit und Biographie des leaders zusammenhängen?' Werden die Probleme so gestellt, dann entgehen sie der Beeinflussung durch mechanistische, psychologische, biologische, empirische Gesetze, die in der Meinung vieler 'Sozialanthropologen' die Struktur einer radikalen, allgemeinen Theorie der Erklärung darstellen sollten. Die Breite des Problems ist größer, als es diesen Autoren scheint: Sie gehen nicht aus dem Bereich der Kulte heraus, beim Versuch, sie zu erklären. Ihr Mißerfolg in der Suche nach gültigen Formeln ist $\mathrm{m}$. E. darauf zurückzuführen, daß sie statt eines positiven Vergleichs - mit dem, was ist - einen Vergleich mit dem Nichts versuchen: mit dem, was geschichtlich nicht existiert." 28

Diese Gedankengänge und Hinweise Lanternaris enthüllen die verschiedenen Standpunkte vollständig. Man muss zugeben, dass er es richtig gesehen hat, dass die geschichtlichen, kulturellen und sozialen Zusammenhänge komplex sind und sich nicht völlig in ein theoretisches Schema pressen lassen. Soweit hat Lanternari recht. Doch er hat unrecht, wenn er meint, dass man eine geschichtliche Erscheinung für sich verstehen kann, so wie er es möchte, ohne eine Theorie aufzustellen, in deren Rahmen die entsprechende Erscheinung richtig, ,verstanden“"bzw. erklärt würde. Dass es sich so verhält, dafür sind Lanternaris Äusserungen ein deutliches Beispiel. Er sagt selbst, dass er eine ,Deutung der Prophetenbewegungen“ geben will. Weiter, er bietet ebenso wie die Sozialanthropologen auch eine Begründung seiner Deutung, denn es, ,ergibt sich einleuchtend, daß für uns in bezug auf die Deutung der Prophetenbewegungen vor allem das letzte der angegebenen Kriterien, nämlich das soziologisch-historische gültig ist, wobei innerhalb dieses methodischen Grundsatzes und in seiner Funktion auch die typologische Analyse (in ihren Untergattungen 'phänomenologisch' und 'klassifizierend') ihre Rechtfertigung findet. Im übrigen ist die soziologisch-historische Art der Fragestellung als einzige geeignet, um auf angemessene Weise der inneren Einheit Rechnung zu tragen, die - auf andere Weise unerklärlich - die beiden kennzeichnendsten Elemente des Prophetismus, nämlich die Gegenwart einer prophetischen Persönlichkeit und einer religiös-sozialen Funktion der Masse, miteinander verbindet. “29

\footnotetext{
${ }^{28} \mathrm{Ib}, 18 \mathrm{f}$.

29 Ib., 465. Über die methodischen Schwierigkeiten ist viel geschrieben worden, cf. Burridge, 171.
} 
Daher besteht zwischen Lanternari und grossenteils allen bisherigen Deutungsversuchen in Wirklichkeit keine Meinungsverschiedenheit darüber, ob eine Theorie die Grundlage einer Erklärung bilden müsse, wohl aber darüber, welches die angemessenste Theorie sei, nach Lanternaris Worten, die Kriterien zur Erklärung der Erscheinungen. Bei Lanternari sind sie ,,soziologisch-historischer" Art, bei Jarvie ,,situational logic".

Ich glaube nicht, dass es möglich ist, sich definitiv für eine dieser beiden so profiliert geäusserten Theorien zu entscheiden. Besonders schwer ist das deswegen, weil die traditionellen Religionshistoriker an die Methoden der Geschichtsforschung gebunden sind. Eine Umstellung, auf welcher Stufe immer, auf die theoretisch-methodischen Untersuchungen der Sozialanthropologen ist schwierig. Es wird jedoch der Religionsgeschichte oder, wie man heute zu sagen pflegt, der Religionswissenschaft, nichts anderes übrig bleiben, wenn sie ihre Berechtigung als legitime Wissenschaft behalten will. Sie wird gezwungen sein, in ihrer methodischen Arbeit die Forderungen der Wissenschaftstheorie zu berücksichtigen. Das könnte dann wiederum einen Einfluss auf das richtigere Verständnis der neuen Religionen haben.

4.1. Die Beschäftigung mit den neuen Religionen hat ein weiteres Mal die altbekannte Wahrheit bestätigt, dass das Material so umfangreich ist, dass man es schlecht überschauen kann. Und das veranlasst einen wiederum, zur Wissenschaftstheorie zurückzukehren, nämlich genau gesagt, zur Frage der Klassifizierung. Bereits viele Forscher haben sich für diese Notwendigkeit ausgesprochen. Einige haben sich geäussert, in welcher Weise sie vorgenommen werden könnte.

Die französische ,Groupe de sociologie des religions" hat sogar zwei Hefte ihrer Veröffentlichung ,Archives de sociologie des religions “ (H. 4 und 5, 1957/58) der Problematik von ,Messianismes et millénarismes" gewidmet. Uns interessieren in diesem Fall nicht die Übersichten über die verschiedenen Bewegungen dieser Art, die dort geboten werden, sondern der Beitrag ,Q Questionnaire sur les messianismes et millénarismes" in Heft 5. Die Herausgeber, d.h. die erwähnte Gruppe, geben einerseits zu, dass eine Typologie erforderlich ist, bekennen aber andererseits, dass die Autoren, die sich mit diesen Bewegungen beschäftigt haben, keine Möglichkeit hatten, eine solche auszuarbeiten, da ihnen eine gemeinsame Sprache fehlt und sie zur Bezeichnung inhaltlich gleicher Begriffe verschiedene Ausdrücke verwenden. Das schafft chaotische Verhältnisse. 
Damit wird die Ausarbeitung des ,Questionnaire" begründet. Um die gewünschte Typologie erarbeiten zu können, müssten die folgenden vier Fragen berücksichtigt werden: ,,1. Dimension d'une sociographie, 2. Typologie des personnages (messianiques) et des groupements (messianiques, millénarists), 3. Signification religieuse des messianismesmillénarismes, 4 . Correlations socioculturelles. “30 Doch blieb es in dieser Sache nur bei einem Aufruf.

Optimistischer beurteilt Gauriglia die Lage, der meint, dass es dennoch möglich sei, eine Typologie auszuarbeiten. Ihm verdanken wir einen zwar kurzen, aber brauchbaren Überblick über die Versuche der Typisierung bis zum Jahre $1959^{31}$. Auf dieser Grundlage hat er seine Typologie geschaffen. Sie stützt sich auf seine besondere Definition dieser Bewegungen und umfasst fünf Merkmale: ,Die Heilserwartungs-Bewegungen sind eine besondere, organisierte Suche nach von Propheten versprochenem Heil, womit psychologische Reaktionen, religiöse, kulturelle, soziale und politische Erneuerungs- und Verhandlungsbestrebungen bzw. Forderungen mehr oder weniger stark verbunden zu sein pflegen. In dieser Definition treten als Grundelemente deutlich fünf hervor: 1. die Natur der Bew egungen oder ihre Grundtendenzen, 2. die Form oder ihre Vollständigkeit, 3. die Künder des Heils (die Propheten) oder die Führer solcher Bewegungen, 4. ihre umweltlichen Aspekte und 5. die Wirkfaktoren dieser Bewegungen. " 32

Wie ersichtlich; entspricht das Gerüst seiner Typologie dem Schema der französischen Religionssoziologen. Ferner gibt er zu, dass er auch die von Linton $^{33}$ und später von Wallace ${ }^{34}$ modifizierten Schemen benutzt habe.

\footnotetext{
${ }^{30}$ Groupe, $88 \mathrm{ff}$.

${ }^{31}$ Gauriglia $54 \mathrm{ff}$. Zu den Versuchen, eine Typologie auszuarbeiten, hat er bemerkt: ,,[ . .] diese bleiben in Wirklichkeit unvollständig, weil ihre Autoren nur von einem ethnologischen Gebiet ausgingen oder mit der Berücksichtigung weniger Fälle sich begnügten " (ib.).

$32 \mathrm{Ib}, 57$.

${ }^{33}$ Cf. Linton, 231.

${ }^{34}$ Cf. Wallace 1956, 266ff. Es ist bezeichnend, daß Wallace nach der Kritik von Smith, Marian, 1959a, 9, gezwungen war zuzugeben, daß seine damals geäußerte Theorie unvollständig sei (cf. Wallace 1959, 25 f: ,,I share Dr. Smith's dissatisfaction which the rather loose set of varieties of revitalization movements which I listed in my original paper (nativistic movements, cargo cults, sects, revolutions etc.). I can justify that set only on the grounds that the terms I chose for varieties were already in the literature and I was concerned to point out what all of these phenomena had in common. They do, furthermore, overlap one another frequently. I was not seriously proposing them as a formal typology, however, since the purpose of the paper
} 
Doch der Optimismus Gauriglia's führt, wenn man seine zum Klassiker gewordene Arbeit kennenlernt, zur Enttäuschung. Er hat gar nicht versucht, die vielen Bewegungen, die in seiner Arbeit betrachtet werden, in das von ihm selbst erarbeitete typologische Schema einzuordnen. Statt dessen hat er eine geographische Übersicht geboten ${ }^{35}$ und alle Probleme der Klassifizierung und Typisierung beiseite gelassen. Man brauchte das hier nicht zu erwähnen, wenn es nicht bezeichnend wäre, dass diese Erscheinung sich wiederholt.

So spricht auch Lanternari in seiner ausgezeichneten Arbeit von der Notwendigkeit der Typisierung, indem er darauf hinweist, nach welchen Grundsätzen sie vorzunehmen wäre. Er erkennt darin zwei ,Untergattungen - 'phänomenologisch' und 'klassifizierend'“"36. Nun könnte man erwarten, dass er einen dieser Typologie entsprechenden Einblick in die diesbezüglichen Bewegungen bieten würde. Doch ebenso wie Guariglia gibt er

\footnotetext{
was to define the species rather than the varieties. I think if I were to undertake to formulate a typology myself now I would tend, as Dr. Smith has done, to abstract from these and other conventional concepts certain crucial dimensions, but then to construct (as Linton did, but with more numerous and somewhat different dimensions) a componential matrix on which the conventional terms might be mapped to show their areas of overlap and divergence." Verständlicherweise ist er danach zu einer neuen Typologie gelangt (1966, 163 ff). Sie lautet wie folgt: ,With regard to the goal of cultural reorganization, it would seem useful, as well as reasonably conventional, to emphasize the attitude of the movement both toward the community's own culture and toward the cultures of other communities (including, particular dominating societies in acculturation situations). Four attitudes would seem to be common: revivalistic, which aims to restore a golden age believed to have existed in the society's past and which ignores or expels the alien group; utopian which aims to achieve a golden age believed to lie in the future, but to be implicit in the evolving patterns of the present, and which also ignores or expels the alien group; assimilative, which aims to import many of the customs of the alien (usually dominant) group, to combine them syncretistically with native customs, and to dissolve social boundaries between the two societies; and expropriative, which aims to import many of the customs of the alien group and to combine them with native customs, but to expel alien persons. The terre sans mal movements were utopian; the Ghost Dance, revivalistic; current American Negro civil rights movements are assimilative (except for the Black Muslims, which are revivalistic); cargo cults, expropriative. " (Ib., 165.)

${ }_{35}$ Es mu $\beta$ angemerkt werden, da $\beta$ Steinbauer, 1970, 1, 17, ss, einen noch vollständigeren historischen und beschreibenden Überblick über die Cargo-Kulte Melanesiens geboten hat, zugleich mit seinen Kommentaren, 1970, 2, 3 ff, denen eine besonders wertvolle, bis ins einzelne ausgearbeitete, typologisch aufgebaute Übersichtstabelle beigefügt ist. Eine überarbeitete, illustrierte Ausgabe erschien 1971. Eine ebenso gute Übersicht über die späteren Formen bietet Kamma, $106 \mathrm{ff}$.

36 Lanternari, 465.
} 
statt dessen einen Überblick über die geographisch orientierten ausgesuchten Bewegungen ${ }^{37}$.

4.2. Es genügt der Hinweis auf diese wenigen Autoren, um zu verstehen, dass man es hier mit besonderen Schwierigkeiten zu tun hat. Doch bevor wir sie aufzeigen, ist hier noch auf einen anderen ganz eigentümlichen Klassifizierungsversuch hinzuweisen. Dieser kann uns auch deshalb besonders interessieren, weil diese Bewegungen hier unter einem rein soziologischen Gesichtspunkt betrachtet werden. Ich denke hier an die neueste Arbeit von Desroche ,,Sociologie de l'espérance“" 38 . Seine Klassifizierung ist deshalb besonders interessant, weil er einerseits versucht, die Stellung der messianistischen Bewegungen im religiösen Leben überhaupt aufzuzeigen, andererseits deren Platz zwischen anderen ähnlichen revolutionären und ideologischen Bewegungen festzustellen trachtet.

Bevor wir uns seinem Klassifizierungsschema zuwenden, ist anzumerken, dass es hier nicht möglich ist, eine kritische Bewertung seiner Grundthese vorzunehmen: , Millénarismes et utopies sont une forme d'imagination collective pour des sociétés opprimées mais l'oppression ne se traduit pas nécessairement par cette unique forme. La modélisation de cette diversité se trouve dessinée dans un récit qu'on peut retenir ici comme involontairement archétypique $[\ldots] .{ }^{\text {‘ } 39}$

Zunächst ist zweierlei zu beachten. Alle diese Bewegungen haben eine gemeinsame Grundlage und gleiche Entwicklungsphasen: ,le temps de

\footnotetext{
37 Dasselbe wiederholt sich auch bei Benz, der ein Werk von mehreren Bänden versprochen hat, in dem die betrachteten Bewegungen geographisch bestimmt sind (Benz, 13).

${ }^{38}$ Die Bedeutung des soziologischen Gesichtspunkts haben in letzter Zeit viele Religionsforscher hervorgehoben, z. B. van Baaren 1970, 82, ganz zu schweigen von denen, die sich unter dem direkten Einflu 3 der amerikanische Sozialanthropologen befinden.

39 Desroche, 223. Ähnlich ib., 225: ,,Parce qu'elle conduit à cette insurrection des dieux, l'imagination collective retrouve dans son éclatement ou dans son éclat et la conscience collective et la mémoire collective. A la conscience collective elle offre la reviviscence de son foyer car elle se déroule comme un quasi-culte de possession : marches sacrées vers la terre sans mal, soulèvements, transes, sacrifices, extases exténuantes ou exterminatoires, festivités exaltantes et iconoclastes, grèves générales et parfois biologiques de sociétés trop établies, jeux au tout pour le tout, allégresses d'un holocauste, démarches rituelles incantatoires et conjuratoires, départs, voyages, exodes, croisades, partir, sortir de l'espace et du temps ... A la mémoire collective elle offre la réactivation de sa caution car si elle se réfère à celle-ci, elle crée ou recrée sa propre référence, elle en appelle d'une tradition moins profonde à une tradition plus profonde, ressuscitant un passé mort ou occulté pour lui restituer sa vie ou sa lumière ; son projet d'un après valide son souvenir de l'avant."
} 
l'oppression", ,,le temps de la résistence", , le temps de la libération" 40 . Zweitens stehen die messianistischen Bewegungen aus soziologischer Sicht stets in gewissen Beziehungen zu anders strukturierten sozialen Erscheinungen und den diese bestimmenden Faktoren. Daher werden sie richtig verstanden, wenn man sie in ihrem Verhältnis zur Religion, Ideologie und Revolution betrachtet. Diese vier Bewegungen (er lässt daneben auch sechs zu, siehe das Schema) sehen grundsätzlich im Konflikt, der seinen Ausdruck in den verschiedenen historisch-sozial bestimmten Situation findet. Hierbei enthüllt sich Desroche's Klassifizierungsschema.

,,Si on inscrit en effet ces quatre termes aux quatre pôles d'un quadrilatère en désignant, pour abréger, chacun des termes par une lettre A, B, C, $\mathrm{D}$, on aperçoit aussitôt l'éventualité du conflit.

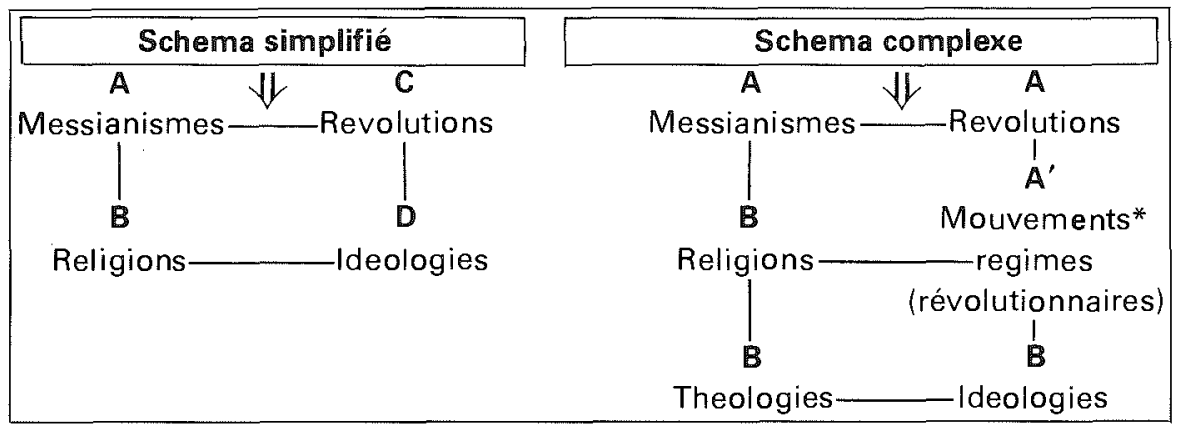

D'un terme à un autre, soit :

1. A contre B

2. A contre $\mathrm{C}$

3. A contre D

4. B contre C

5. B contre D

6. C contre $D$ chacun des termes étant susceptible d'une opposition à chacun de trois autres

${ }^{40}$ Cf. ib., 171. Ganz besonders betont er die eigentümlichen Beziehungen zwischen messianistischen und revolutionären Bewegungen: ,,Tantôt la genèse va du messianisme religieux à l'idéologie révolutionnaire. Et tantôt, au contraire, de l'idéologie révolutionnaire au messianisme religieux. L'amalgame lui-même se fait tantôt sur une accentuation - messianisme religieux s'amalgamant à une idéologie révolutionnaire - et tantôt sur une autre - messianisme religieux amalgamant à lui-même une telle idéologie. Mais s'exprimer ainsi, c'est en dire trop ou pas assez. Car, comme on l'a déjà souligné, ces couples sont involués les uns dans les autres. Si on conçoit que 'messianisme' et 'révolution' sont inclus l'un et l'autre dans la catégorie du changement social radical, à la fois économique et culturel, le changement culturel radical qu'est un messianisme n'ira pas sans amorcer le changement économique qu'est une révolution." (Ib., 170.) 
D'un couple de termes à un autre couple, soit :

chacun des trois couples

7. $\mathrm{A}+\mathrm{B}$ contre $\mathrm{C}+\mathrm{D}$ possibles à chaque terme

8. $\mathrm{A}+\mathrm{C}$ contre $\mathrm{B}+\mathrm{D}\} \quad$ étant susceptible d'une

9. $\mathrm{A}+\mathrm{D}$ contre $\mathrm{B}+\mathrm{C}\}$ opposition aux trois couples adverses.

D'une triade de termes à un quatrième exclu, soit :
10. $\mathrm{A}+\mathrm{C}+\mathrm{D}$ contre $\mathrm{B}$
chaque triade étant sus-
11. $\mathrm{A}+\mathrm{B}+\mathrm{D}$ contre $\mathrm{C}$ ceptible d'une opposition
12. $\mathrm{A}+\mathrm{B}+\mathrm{C}$ contre $\mathrm{D}$
13. $\mathrm{B}+\mathrm{C}+\mathrm{D}$ contre $\mathrm{A}$ au quatrième terme exclu par elle.

La grille peut paraître sophistiquée. A tort. Elle pâtit seulement de l'imprécision des termes en présence. " 41

Dieses Schema ist in der Hinsicht bedeutsam, weil es vor allem die Möglichkeit bietet, spezifisch religiöse Bewegungen in andere ähnliche Bewegungen einzuordnen. Der Autor gibt jedoch zu, dass sein Klassifizierungsschema Kritik hervorruft wegen dessen - wie er selbst sagt - sophistischen Charakters. Das ist zwar wahr, aber das bezieht sich mehr oder weniger auf jeden Versuch einer Schematisierung. Doch glaubt der Autor, dass er mit seinen dem Schema beigefügten Erklärungen bestätigt habe, dass dieses dennoch dazu verhelfen könne, den eigentlichen Sinn der oft unverständlichen und paradoxen Bewegungen und deren Konflikte zu erhel$1 \mathrm{en}{ }^{42}$.

Unabhängig davon, ob man der Ausgangsposition Desroche's und der Theorie der permanenten Konfliktsituation zustimmt oder nicht, ist dieses Schema das vollständigere, das hilft, mit Tillichs Worten, sich auf dem weiten Felde der religiösen, quasi-religiösen, pseudo-religiösen und anderer Bewegungen und über die von ihnen hervorgerufenen Konfliktsituationen zu orientieren. Aber dieses Klassifizierungsschema enthüllt auch die hier mehrfach erwähnten Schwierigkeiten wie bei allen theoretischen Schemata, dass man sich eine Unterteilung dieser Gruppe in weitere Untergruppen mit ungezählten neuen Kombinationen vorstellen kann.

\footnotetext{
${ }^{41} \mathrm{Ib} ., 174 \mathrm{f}$. Er hat diesem Schema als Grundlage sehr bedeutsame Erklärungen und Hinweise auf konkrete Bewegungen angefügt.

${ }^{42}$ Cf. ib., 175.
} 
Jetzt verstehen wir, wenn wir uns wieder den Autoren zuwenden, die bei der geographischen Einteilung der Bewegungen verharrten, deren Schwierigkeiten besser. Die von ihnen postulierten theoretischen Klassifizierungsprinzipien waren in der Praxis nicht anwendbar, daher musste man zur geographischen Einteilung zurückkehren, die, worauf bereits hingewiesen wurde, als solche nichts über das Wesen dieser Bewegungen aussagt. Sie hatten auch in der Hinsicht Schwierigkeiten, dass sie sich mit einer gewissen Auswahl der Bewegungen begnügen mussten. Doch war diese Auswahl nicht durch die Bewegungen selbst begründet. Es fehlt an einer grundsätzlichen Motivierung durch deren eigentliches Wesen. Nach dieser Bekanntmachung mit verschiedenen Klassifizierungsversuchen der religiösen Bewegungen kann man feststellen, dass die Forscher sich darüber klar sind, dass eine Klassifizierung als Bedingung wissenschaftlicher Forschung notwendig ist, aber ebenso klar liegen die Schwierigkeiten zu deren Ausarbeitung auf der Hand ${ }^{43}$.

5.1. Der Einblick in die Problematik der Erforschung der neuen religiösen Formen führt zu einigen bedeutsamen Schlüssen. Erstens sind grosse Schwierigkeiten in bezug auf die Terminologie zu bemerken. Hier sind neben einer ungenauen und inkonsequenten Terminologie Hindernisse zu erkennen, die Termini der im Christentum verwurzelten europäischen Tradition auf religiöse Bewegungen zu übertragen, die anderen Kulturen angehören. Zweitens sind lebhafte Diskussionen um die Fragen im Gange, die die Motive der Entstehung dieser Bewegungen berühren sowie die Faktoren, die deren Riten und das religiöse Leben im weitesten Sinne bestimmen. Dritten s zeigt die Problematik der neuen Religionen klarer als andere Gebiete der religionswissenschaftlichen Forschung, dass die Forderung nach Zusammenarbeit mit anderen Wissenschaftsbereichen, vor allem mit dem der Soziologie, eine absolute Notwendigkeit ist. Viertens verlangt die Er-

\footnotetext{
${ }^{43}$ In jeder Hinsicht lehrreich ist die Diskussion, die bereits 1959 stattfand zwischen Smith, Marian, $1959 a$ und $1959 b$, Wallace, 1959, und Voget, als deren Resultat die erstere Gedanken geäussert hat, die ebenso wie damals auch jetzt helfen, die derzeitige Situation in der Frage der Klassifizierung der neuen Religionen zu verstehen: ,, One of the values of an accepted classification is that it tends to eliminate some of the vagaries of personal bias and concentrate attention on generally significant aspects of the material. The danger of classification lies of course in the rigidity which it breeds. Warnings against this particular evil must be frequently reiterated, but it hardly arises in the present discussion. If this rigidity can be avoided, then the dimensions that we have visualized may indeed aid in a proper ass essment of these movements and thus add a sizable crumb to the larger field." (Smith, Marian, 1959b, 28.)
} 
forschung der neuen religiösen Bewegungen von der Religionswissenschaft, dass sie sich unter den anderen humanistischen Wissenschaften legitimiert, indem sie ihre Methoden präzisiert.

\section{Literaturverzeichnis}

Anderson, I., 1972, Christianity and Comparative Religion. London

ASR - Archives de sociologie des religions.

Benz, E., 1971, Neue Religionen. Stuttgart.

Bergmann, G., 1934, Eine papuanische Schwärmerei. Neuendettelsauer Missionsblatt.

Bianchi, U., 1964, Probleme der Religionsgeschichte. Kleine Vandenhoeck-Reihe 203/204.

Göttingen.

Biezais, H., 1969, Tendenser i nutida messianska rörelser. Religion och Bibel 28.

Bouguet, A., 1958, The Christian Faith and non-Christian Religions. London.

Burridge, K., 19ó9, New Heaven, New Earth. Oxford.

Cohn, N., 1961, Das Ringen um das tausendjährige Reich. Bern.

Desroche, H., 1973, Sociologie de l'espérance. Paris.

Evans, C., 1973, Cults of Unreason. London.

Groupe, 1958 G[roupe de]. S[ociologie des]. R[eligions], Questionnaire sur les messianismes et millénarismes. ASR 5.

Guariglia, G., 1959, Prophetismus und Heilserwartungsbewegungen als völkerkundliches und religionsgeschichtliches Problem. Wiener Beiträge zur Kulturgeschichte und Linguistik 13. Horn-Wien.

Guiart, J. \& Worsley, P., 1958, La répartition des mouvements millénaristes en Melanesie. ASR 5 .

Haack, F.-W., 1973, Rendezvous mit dem Jenseits. Hamburg.

Häresien, 1961, Häresien der Zeit. Hrsg. A. Böhm. Freiburg.

Hallencreutz, C., 1966, Kraemer towards Tambaram. Diss. Uppsala. Studia Missionalia Upsaliensia 7. Uppsala.

Hobsbawm, E., 1963, Primitive Rebels. Manchester.

Jarvie, I., 1970, The Revolution in Anthropology. London.

- 1973, Functionalism. Minneapolis.

Kamma, F., 1972, Koreri. Koninklijk institut voor Taal-, Land- en Volkenkunde. Translation series 15 . The Hague.

Kraemer, H., 1956, Religion and the Christian faith. London.

Köberle, A., 1965, Psychopathologisches im religiösen Geschehen. Massenwahn.

Lanczkowski, G, , 1974, Die neuen Religionen. Frankfurt a. M.

Lanternari, V., s. a. Religiöse Freiheits- und Heilsbewegungen unterdrückter Völker. Soziologische Texte 33. Darmstadt.

Linton, R., 1943, Nativistic movements. American Anthropologist 45.

Lommel, A., 1953, Der 'Cargo-Kult' in Melanesien. Zeitschrift für Ethnologie.

Massenwahn, 1965, Massenwahn in Geschichte und Gegenwart. Hrsg. v. W. Bitter. Stuttgart.

Mensching, G., 1974, Der offene Tempel. Stuttgart.

Montauban, P., 1934, Schwarmgeister auf den Salomonen. Kreuz und Karitas.

Mühlmann, W., 1961, Chiliasmus und Nativismus. Berlin.

Natzmer, G., 1958, Die Geistigen Mächte unseres Jahrhunderts. Berlin.

Schüttler, G., 1971, Die letzten tibetischen Orakelpriester. Wiesbaden. 
Smith, Marian, 1959a, Towards a classification of cult movements. Man 59.

- 1959b. [Replay to A. Wallace and F. Voget] Man 59.

Steinbauer, F., 1970, Die Cargo-Kulte in Melanesien 1-2. Diss. Nürnberg.

- 1971, Melanesische Cargo-Kulte. München.

Van Baaren, T., 1970, Systematische Religionswissenschaft. Nederlands Theologisch Tijdschrift.

- 1972, Vi människor. Stockholm.

Voget, F., 1959, [Reply to Marian Smith] Man 59.

Wallace, A., 1956, Revitalization movements. American Anthropologist 58.

- 1959, [Reply to Marian Smith] Man 59.

- 1966, Religion, an Anthropological View. New York.

Worsley, P., 1968, The Trumpet Shall Sound. S.1.

Zaehner, R., 1958, At Sundry Time. London. 